\title{
HUBUNGAN DAN PENGARUH AUDIT INTERNAL ATAS FUNGSI PRODUKSI UNTUK MENILAI EFEKTIVITAS DAN EFISIENSI PROSES PRODUKSI
}

\author{
Gen Norman Thomas \\ Accounting Department, Faculty of Economic and Communication, BINUS University \\ Jln. KH Syahdan No 9, Kemanggisan-Palmerah, Jakarta Barat 11480 \\ gen_nt@binus.ac.id
}

\begin{abstract}
The objective of this study is to examine the relationship and the influence between the internal audit toward production function to assess effectiveness and efficiency of the production process at PT.Sumber Nitrat Jaya. The type of research is survey with descriptive research and analysis technique used is the analysis of qualitative data and quantitative data analysis. The sample was 30 respondents. Based on the significance test of correlation coefficients between the variables, it shows a correlation between internal audit with the production function to assess the effectiveness and efficiency of the production process obtained a correlation coefficient of 0.950, which means there is a very strong relationship. By testing the hypothesis that the correlation of the results obtained there is a significant relationship between internal audit with the production function to assess the effectiveness and efficiency of production processes in PT Sumber Nitrat Jaya, because of Hol was rejected and Hal was accepted where t count HAI>T Table (16.156>2.048). Significance test based on the regression parameter showed a simple linear regression of $Y=4.523+0.581 X+\varepsilon$. This is supported by testing hypotheses derived regression $t$ count $>T$ Table $(16.156>2.048)$ then there is a significant influence of internal audit toward the production function to assess the effectiveness and efficiency of production processes in PT Sumber Nitrat Jaya because Ho2 was rejected and Ha2 was accepted. This is also supported by the R square value of 0.903 obtained results, or $90.3 \%$. This shows the contribution of internal audit in explaining the effectiveness and efficiency of production processes by $90.3 \%$ while the remaining $9.7 \%$ is explained by other factors not examined or not included in the model.
\end{abstract}

Keywords: internal audit, effectiveness, efficiency, production process

\begin{abstract}
ABSTRAK
Penelitian ini bertujuan untuk mengungkapkan hubungan dan pengaruh antara audit internal dengan fungsi produksi untuk menilai efektivitas dan efisiensi proses produksi pada PT. Sumber Nitrat Jaya. Jenis penelitian ini adalah penelitian survey dengan taraf penjelasan deskriptif dan teknik analisa yang digunakan adalah analisa data kualitatif dan analisa data kuantitatif. Sampel yang digunakan sebanyak 30 responden. Berdasarkan uji signifikansi korelasi antar variabel menunjukkan hasil koefisien korelasi antara audit internal dengan fungsi produksi untuk menilai efektivitas dan efisiensi proses produksi diperoleh nilai koefisien korelasi sebesar 0,950 yang berarti terdapat hubungan yang sangat kuat. Dengan pengujian hipotesis korelasi diperoleh hasil bahwa terdapat hubungan yang signifikan antara audit internal dengan fungsi produksi untuk menilai efektivitas dan efisiensi proses produksi di PT Sumber Nitrat Jaya, karena Hol ditolak dan Hal diterima dimana $t_{\text {hitung }}>t_{\text {tabel }}(16,156>2,048)$. Berdasarkan uji signifikansi parameter regresi menunjukkan hasil analisis regresi linear sederhana sebesar $\hat{Y}=4,523+0,581 X+\varepsilon$. Hal ini didukung dengan pengujian hipotesis regresi diperoleh $t_{\text {hitung }}>t_{\text {tabel }}(16,156>2,048)$ maka ada pengaruh yang signifikan antara audit internal terhadap fungsi produksi untuk menilai efektivitas dan efisiensi proses produksi di PT. Sumber Nitrat Jaya karena Ho2 ditolak dan Ha2 diterima. Hal ini juga didukung dengan nilai $R$ square diperoleh hasil 0,903 atau 90,3\%. Hal ini menunjukkan besarnya kontribusi dari audit internal dalam menjelaskan efektivitas dan efisiensi proses produksi sebesar 90,3\% sedangkan sisanya 9,7\% dijelaskan oleh faktor lain yang tidak diteliti atau tidak dimasukkan dalam model.
\end{abstract}

Kata kunci: Audit Internal, Efektivitas, Efisiensi, Proses Produksi 


\section{PENDAHULUAN}

Audit internal adalah elemen penting bagi suatu perusahaan untuk mengungkapkan ketaatan antara pelaksanaan kebijakan manajemen perusahaan dengan kenyataan yang dihadapi. Ketaatan menjadi penting karena ketaatan merupakan unsur utama dalam usaha membangun kepercayaan akan tugas-tugas audit internal. Audit internal dilakukan oleh auditor internal perusahaan dan auditor internal ini tidak memberikan opini atas pekerjaannya karena pihak penggunanya menganggap bahwa para auditor internal ini tidak independen, masih merupakan bagian dari perusahaan. Arens dan Loebbecke (2003) mengatakan bahwa audit internal merupakan penelaahan atas bagian manapun dari prosedur dan metode operasi suatu perusahaan untuk menilai efisiensi dan efektivitasnya. Umumnya, pada saat selesainya audit internal, auditor akan memberikan sejumlah saran kepada manajemen untuk memperbaiki jalannya operasi perusahaan. Dari pendapat diatas dapat diketahui bahwa salah satu hasil dari kegiatan audit internal adalah memberikan saran konstruktif bagi perbaikan perusahaan kedepan, oleh sebab itu saran yang disampaikan kepada pihak manajemen haruslah sarat dengan nuansa peningkatan efektivitas dan efisiensi. Sebagaimana disampaikan oleh Jusup (2001) bahwa audit internal adalah pengkajian (review) atas setiap bagian dari prosedur dan metoda yang diterapkan suatu perusahaan dengan tujuan untuk mengevaluasi efisiensi dan efektivitas. Hasil akhir suatu kegiatan audit internal biasanya berupa rekomendasi kepada manajemen untuk perbaikan operasi.

Dilanjutkan oleh Agoes (2004) bahwa tujuan umum dari audit internal adalah: a). Untuk menilai kinerja dari manajemen dan berbagai fungsi dalam perusahaan. b).Untuk menilai apakah berbagai sumber daya (manusia, mesin, dana, harta lainnya) yang dimiliki perusahaan telah digunakan secara efisien dan ekonomis. c).Untuk menilai efektivitas perusahaan dalam mencapai tujuan yang telah ditetapkan oleh manajemen puncak. d).Untuk memberikan rekomendasi kepada manajemen puncak untuk memperbaiki kelemahan-kelemahan yang terdapat dalam penerapan pengendalian intern, sistem pengendalian manajemen, dan prosedur operasional perusahaan dalam rangka meningkatkan efisiensi, keekonomisan dan efektivitas dari kegiatan operasi perusahaan. Berdasarkan pendapat Agoes di atas diketahui bahwa audit internal atas fungsi produksi menjadi fokus utama perusahaan untuk menilai efektivitas dan efisiensi proses produksi. Fungsi produksi adalah salah satu fungsi yang ada di dalam perusahaan yang bertugas bertanggung jawab di bidang produksi. Oleh Mulyadi (2000) dikatakan bahwa fungsi produksi bertugas untuk mengolah bahan baku menjadi produk jadi, sedangkan Swastha dan Sukotjo (2002) lebih menyorot mengenai proses produksi, sebagaimana dikatakan bahwa proses produksi adalah pengubahan bahan-bahan dari sumber-sumber menjadi hasil yang diinginkan konsumen. Hasil itu dapat berupa barang ataupun jasa”.

Dari aspek efektivitas dan efisiensi dikatakan oleh Kartikahadi dalam Agoes (2004), bahwa a). Efektivitas dimaksud bahwa produk akhir suatu kegiatan operasi telah mencapai tujuannya baik ditinjau dari segi kualitas hasil kerja, kuantitas hasil kerja maupun batas waktu yang ditargetkan. b). Kehematan (economy) berarti cara penggunaan sesuatu barang (hal) secara berhati-hati dan bijak (prudent) agar diperoleh hasil yang terbaik. c). Efisiensi berarti bertindak dengan cara yang dapat meminimalisir kerugian atau pemborosan sumber daya dalam melaksanakan atau menghasilkan sesuatu. Berdasarkan semua uraian diatas mensyaratkan betapa pentingnya semua kegiatan perusahaan harus dilaksanakan dengan sebaik-baiknya dengan mengacu pada peningkatan efektivitas dan efisiensi. Audit internal atas fungsi produksi yang sudah dilaksanakan oleh perusahaan tidak akan dapat menjamin bahwa peningkatan efektivitas dan efisiensi telah tercapai.

Penelitian ini bertujuan meneliti kembali penelitian terdahulu yang dilakukan oleh Ta Liana dengan judul Audit Internal Terhadap Proses Produksi PT Adhytama Cipta Kreasi menunjukkan bahwa PT Adhytama Cipta Kreasi yang merupakan perusahaan yang bergerak di bidang manufaktur dengan jenis produksi billboard, neon boks, sales counter, tenda promosi dengan hasil penelitian kegiatan produksi sudah efektif tetapi belum efisien. Kemudian penelitian yang lain yang dilakukan 
oleh William Lesmana dengan judul Audit internal Terhadap Efektivitas dan Efisiensi Proses Produksi Dempul Merk "Dank Deutz" Pada PT Victorindo Kimiatama dengan hasil PT Victorindo Kimiatama dalam melaksanakan audit operasional atas proses produksi telah berjalan dengan efektif.

\section{METODE}

Penelitian ini menggunakan data primer dimana populasi penelitian ini adalah seluruh karyawan PT Sumber Nitrat Jaya sebanyak 62 orang karyawan. PT Sumber Nitrat Jaya bergerak dalam bidang industri kimia berbasis Nitrat yang memproduksi Asam Nitrat dan Ammonium Nitrat, Ammonium Nitrat ini merupakan bahan baku untuk peledak atau handak. Pemilihan sampel berdasarkan sample random sampling. Kriteria sampel adalah karyawan yang pekerjaannya berkaitan bagian produksi atau proses produksi sebanyak 30 orang responden, pemilihan 30 responden sudah sesuai dengan pendapat Roscoe (1975) dalam Sekaran, Uma (2000) yang mengatakan: "Sample size larger than 30 and less than 500 are appropriate for most research." Semua data untuk penelitian ini sudah tersedia lengkap.

Yang menjadi variabel dependen dalam penelitian ini adalah Audit internal merupakan kegiatan yang perlu dilakukan oleh perusahaan untuk mengungkapkan dan memberi informasi kepada manajemen mengenai berbagai masalah operasional, sehingga kegiatan yang dilakukan oleh perusahaan menjadi lebih efektif, efisien dan ekonomis. Pengukuran audit internal dilakukan dengan pengamatan pemisahan fungsi dan pemeriksaan terhadap bukti, berupa: sampel kartu biaya per unit produk selesai, sampel kartu biaya, formulir cek, catatan akuntansi dan kelengkapan otorisasi.

\section{Variabel Independen}

Efektivitas dan efisiensi proses produksi adalah suatu kegiatan atau proses yang mengtransformasikan masukan (input) menjadi hasil keluaran (output), selain itu dapat diartikan juga sebagai kegiatan yang berhubungan dengan usaha untuk menciptakan atau menambah kegunaan atau utilitas suatu barang atau jasa. Efektivitas dan efisiensi proses produksi diukur dengan perhitungan fisik persediaan, dan berbagai pengujian, antara lain; pengujian kompilasi, pengujian harga (pricing test) dan pengujian adjustment.

\section{HASIL DAN PEMBAHASAN}

\section{Uji Normalitas}

Pengujian normalitas data menggunakan Kolmogorov-Smirnov One Sample Test untuk mengetahui apakah distribusi data yang diperoleh berdistribusi normal atau tidak. 
Tabel 1 Kolmogorov-Smirnov One Sample Test

\begin{tabular}{|ll|r|r|}
\hline & & & $\begin{array}{c}\text { Efektifitas } \\
\text { dan Efisiensi } \\
\text { Proses } \\
\text { Produksi }\end{array}$ \\
\hline N & & Audit internal & 30 \\
Normal Parameters a,b & Mean & 38,1333 & 55,7333 \\
Most Extreme & Std. Deviation & 15,87393 & 9,70579 \\
Differences & Absolute &, 120 &, 119 \\
& Positive &, 077 &, 070 \\
Kolmogorov-Smirnov Z & Negative &,- 120 &,- 119 \\
Asymp. Sig. (2-tailed) & &, 656 &, 650 \\
\hline
\end{tabular}

a. Test distribution is Normal

b. Calculated from data.

Sumber: Data Olahan SPSS Ver. 13.00

Kolmogorov-Smirnov One Sample Test menunjukkan bahwa hasil uji normalitas data untuk audit internal dengan probalitas signifikansi sebesar 0,782 >0,05 berarti data berdistribusi normal. Demikian pula untuk efektivitas dan efisiensi proses produksi dengan probabilitas signifikansi $0,793>$ 0,05 berarti data juga berdistribusi normal.

\section{Statistik Deskriptif} berikut.

Statistik deskriptif yang dapat disajikan untuk penelitian ini adalah sebagaimana tampak

Tabel 2 Statistik Deskriptif

\begin{tabular}{|l|r|r|}
\hline & & $\begin{array}{c}\text { Efektifitas } \\
\text { dan Efisiensi } \\
\text { Proses } \\
\text { Produksi }\end{array}$ \\
\hline $\mathrm{N}$ & Valid & Audit internal \\
Mean & 30 & 30 \\
Median & 0 & 0 \\
Mode & 88,1333 & 55,7333 \\
Std. Deviation & 89,0000 & 57,0000 \\
Variance & $80,00^{\mathrm{a}}$ & $57,00^{\mathrm{a}}$ \\
Range & 15,87393 & 9,70579 \\
Minimum & 251,982 & 94,202 \\
Maximum & 60,00 & 37,00 \\
Sum & 56,00 & 36,00 \\
\hline
\end{tabular}

a. Multiple modes exist. The smallest value is shown

Sumber: Data Olahan SPSS Ver. 13.00

\section{Uji Hipotesis}

Pengujian yang dilakukan terhadap hipotesis yang sudah dikemukakan untuk mengetahui apakah hipotesis tersebut diterima atau ditolak, untuk itu pengujian hipotesis dimulai dengan berikut. 


\section{Uji Korelasi}

Tabel 3 Uji Korelasi

\begin{tabular}{|ll|r|r|}
\hline & & \multicolumn{1}{|c|}{$\begin{array}{c}\text { Efektifitas } \\
\text { dan Efisiensi } \\
\text { Proses } \\
\text { Produksi }\end{array}$} \\
\hline Audit internal & Pearson Correlation & Audit internal &, $950^{\star \star}$ \\
& Sig. (2-tailed) & &, 000 \\
& $\mathrm{~N}$ & 30 & 30 \\
\hline Efektifitas dan Efisiensi & Pearson Correlation &, $950^{\star \star}$ & 1 \\
Proses Produksi & Sig. (2-tailed) &, 000 & 30 \\
& $\mathrm{~N}$ & 30 & \\
\hline
\end{tabular}

**. Correlation is significant at the 0.01 level (2-tailed).

Sumber: Data Olahan SPSS Ver. 13.00

Korelasi sederhana dengan memperoleh $\mathrm{r}$ sebesar 0,950 . Hal tersebut menunjukkan hubungan antara audit internal atas fungsi produksi untuk menilai efektivitas dan efisiensi proses produksi adalah sangat kuat dan searah (positif).

\section{Uji Signifikansi Korelasi}

Bertujuan untuk mengetahui apakah terdapat atau tidak hubungan antara audit internal (X) dengan fungsi produksi untuk menilai efektivitas dan efisiensi proses produksi (Y).

\section{Hipotesis pertama}

Ho1 : terdapat hubungan antara audit internal dengan fungsi produksi untuk menilai efektivitas dan efisiensi proses produksi.

Langkah-langkah pengujian hipotesis :

1. Menentukan Ho dan Ha (bentuk uji)

Ho1 : $\rho=0$, tidak terdapat hubungan antara audit internal dengan fungsi produksi untuk menilai efektivitas dan efisiensi proses produksi

Ha1 $: \rho \neq 0$, terdapat hubungan antara audit internal dengan fungsi produksi untuk menilai efektivitas dan efisiensi proses produksi

2. Menetapkan taraf nyata $(\alpha)$ / tingkat keyakinan (1- $\alpha)$, tingkat keyakinan sebesar $95 \%$ dan taraf nyata $\alpha=5 \%$

3. Memilih uji statistik

$$
t_{\text {hitung }}=\frac{r \sqrt{n-2}}{\sqrt{1-r^{2}}}
$$

4. Menghitung nilai statistik uji $\mathrm{t}$

$$
t_{\text {hitung }}=\frac{r \sqrt{n-2}}{\sqrt{1-r^{2}}}=\frac{0,950 \sqrt{30-2}}{\sqrt{1-\left(0,950^{2}\right)}}=16,156
$$


5. Membandingkan nilai statistik uji dengan daerah kritis

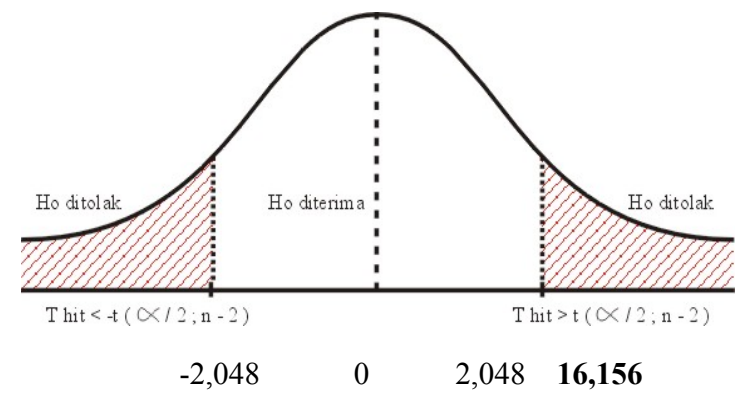

Gambar 1 Perbandingan Nilai Stastitik Uji dengan Daerah Kritis

Berdasarkan perhitungan di atas bahwa $\mathrm{t}$ hitung $>\mathrm{t}$ tabel atau 16,156 $>2,048$ dan menunjukkan probabilitas signifikansi $0,000<0,05$ maka Ho1 ditolak. Ini berarti bahwa terdapat hubungan positif dan signifikan antara audit internal dengan fungsi produksi untuk menilai efektivitas dan efisiensi proses produksi, dengan demikian hipotesis penelitian Ha1 dinyatakan diterima.

\section{Uji Regresi}

Uji regresi sederhana digunakan untuk mengetahui ada tidaknya kelinieran pengaruh audit internal terhadap fungsi produksi untuk menilai efektivitas dan efisiensi proses produksi. Perhatikan Tabel 4 berikut.

Tabel 4 Coefficients

\begin{tabular}{|c|c|c|c|c|c|c|c|c|}
\hline \multirow[b]{2}{*}{ Model } & & \multicolumn{2}{|c|}{$\begin{array}{c}\text { Unstandardized } \\
\text { Coefficients }\end{array}$} & \multirow{2}{*}{\begin{tabular}{|c|}
$\begin{array}{c}\text { Standardized } \\
\text { Coefficients }\end{array}$ \\
Beta \\
\end{tabular}} & \multirow[b]{2}{*}{$t$} & \multirow[b]{2}{*}{ Sig. } & \multicolumn{2}{|c|}{ Collinearity Statistics } \\
\hline & & $\mathrm{B}$ & Std. Error & & & & Tolerance & VIF \\
\hline \multirow[t]{2}{*}{1} & (Constant) & 4,523 & 3,219 & & 1,405 & ,171 & & \\
\hline & Audit interna &, 581 & ,036 & ,950 & 16,156 &, 000 & 1,000 & 1,000 \\
\hline
\end{tabular}

a. Dependent Variable: Efektifitas dan Efisiensi Proses Produksi

Sumber: Data Olahan SPSS Ver. 13.00

Berdasarkan hasil perhitungan diperoleh konstanta (intercept) a sebesar 4,523 dan koefisien regresi b sebesar 0,581 sehingga bentuk persamaan regresi linear sederhana adalah:

$$
\hat{\mathbf{Y}}=\mathbf{4 , 5 2 3}+\mathbf{0 , 5 8 1 X}+\varepsilon
$$

Pengaruh audit internal terhadap fungsi produksi untuk menilai efektivitas dan efisiensi proses produksi adalah searah (positif), ditunjukkan pada koefisien regresi atau nilai $b$ dalam persamaan regresi tersebut 0,581 yang berarti bahwa setiap kenaikan audit internal 1 satuan maka akan diikuti dengan kenaikan efektivitas dan efisiensi proses produksi sebesar 0,581 satuan. Demikian pula jika audit internal mengalami penurunan 1 satuan, efektivitas dan efisiensi proses produksi akan mengalami penurunan sebesar 0,581 satuan. Koefisien a (intercept) adalah sebesar 4,523 berarti apabila tidak terdapat audit internal $(\mathrm{X}=0)$, maka efektivitas dan efisiensi proses produksi sebesar 4,523 satuan. 


\section{Uji Signifikasi Parameter Regresi}

\section{Hipotesis Kedua}

Ha2 : terdapat pengaruh audit internal terhadap fungsi produksi untuk menilai efektivitas dan efisiensi proses produksi

\section{Pengujian hipotesis:}

1. Ho2: $\beta=0$, tidak terdapat pengaruh audit internal terhadap fungsi produksi untuk menilai efektivitas dan efisiensi proses produksi

Ha2: $\beta \neq 0$, terdapat pengaruh audit internal terhadap fungsi produksi untuk menilai efektivitas dan efisiensi proses produksi

2. Dengan taraf nyata ta $(\alpha)=5 \%$ atau tingkat keyakinan $(1-\alpha)=1-5 \%=95 \%$. Semakin tinggi tingkat kepercayaan, maka semakin akurat hasil yang diperoleh.

3. $\quad$ T tabel $=\mathrm{t}(\alpha / 2)(\mathrm{n}-2)=\mathrm{t}(0,025)(30-2)=2,048$

4. Statistik t hitung

Tabel 5 Coefficients

\begin{tabular}{|c|c|c|c|c|c|c|c|c|}
\hline \multirow{2}{*}{\multicolumn{2}{|c|}{ Model }} & \multicolumn{2}{|c|}{$\begin{array}{c}\text { Unstandardized } \\
\text { Coefficients }\end{array}$} & \multirow{2}{*}{$\begin{array}{c}\begin{array}{c}\text { Standardized } \\
\text { Coefficients }\end{array} \\
\text { Beta }\end{array}$} & \multirow[b]{2}{*}{$\mathrm{t}$} & \multirow[b]{2}{*}{ Sig. } & \multicolumn{2}{|c|}{ Collinearity Statistics } \\
\hline & & B & Std. Error & & & & Tolerance & VIF \\
\hline & (Constant) & 4,523 & 3,219 & & 1,405 & ,171 & & \\
\hline & Audit internal & ,581 & ,036 & 950 & 16,156 & ,000 & 1,000 & 1,000 \\
\hline
\end{tabular}

a. Dependent Variable: Efektifitas dan Efisiensi Proses Produksi

Sumber: Data Olahan SPSS Ver. 13.00

5. Menentukan daerah kritis

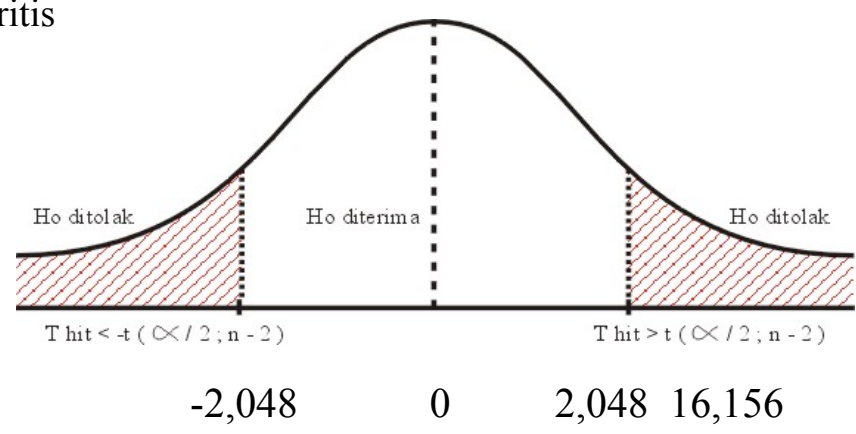

6. Kriteria pengujian

Ho ditolak, Ha diterima $t$ hitung $>\mathrm{t}(\alpha / 2 ; \mathrm{n}-2)$

7. Kesimpulan

Dengan $\alpha=5 \%$ dan $\mathrm{n}=30$ atau $\mathrm{t}(0,025 ; 30-2)$, diperoleh $\mathrm{t}$ tabel sebesar 2,048 dapat dilihat $\mathrm{t}$ hitung $=16,156>\mathrm{t}$ tabel $=2,048$ dan dengan probabilitas signifikansi $0,000<0,05$ maka dikatakan signifikan dan Ho2 ditolak, itu artinya terdapat pengaruh positif yang signifikan audit internal terhadap fungsi produksi untuk menilai efektivitas dan efisiensi proses produksi, sehingga hipotesis penelitian $\mathrm{Ha} 2$ diterima. 


\section{Koefisien Determinasi}

Berikut hasil koefisien determinasi dari R square:

Tabel 6 Model Summary

\begin{tabular}{|l|r|r|r|r|r|}
\hline Model & \multicolumn{1}{|c|}{ R } & R Square & $\begin{array}{c}\text { Adjusted } \\
\text { R Square }\end{array}$ & $\begin{array}{c}\text { Std. Error of } \\
\text { the Estimate }\end{array}$ & $\begin{array}{c}\text { Durbin- } \\
\text { Watson }\end{array}$ \\
\hline 1 &, $950^{\mathrm{a}}$ &, 903 &, 900 & 3,07439 & 1,323 \\
\hline
\end{tabular}

a. Predictors: (Constant), Audit internal

b. Dependent Variable: Efektifitas dan Efisiensi Proses Produksi

Sumber: Data Olahan SPSS Ver. 13.00

Dengan melihat hasil perhitungan di atas, dimana $\mathrm{R}$ square sebesar 0,903 atau 90,3\%, ini menunjukkan besarnya kontribusi dari audit internal dalam menjelaskan efektivitas dan efisiensi proses produksi sebesar $90,3 \%$. Sedangkan sisanya $9,7 \%$ dijelaskan oleh faktor lain yang tidak diteliti atau tidak dimasukkan dalam model.

\section{Uji Beda Dua Rata-rata}

Uji t untuk dua sampel yang berpasangan (paired sample t test) digunakan untuk pengujian perbandingan dua sampel yang berpasangan atau diartikan sebuah sampel dengan subjek yang sama namun mengalami dua perlakuan atau pengukuran yang berbeda. Data yang diolah adalah data yang bersumberkan dari rencana dan realisasi dengan satu kali pengujian yaitu atas produksi triwulan I tahun 2007 sampai dengan triwulan IV tahun 2008 sehingga $\mathrm{N}$ yang digunakan sebanyak 8. Pengujian ke -2 (diduga terdapat perbedaan rata-rata yang signifikan antara rencana dengan realisasi produksi). Lihat tabel 7 berikut.

Tabel 7 Rencana dan Realisasi Produksi

\begin{tabular}{crrrrrr}
\hline $\mathbf{N}$ & $\begin{array}{c}\text { Rencana } \\
\mathbf{X}_{\mathbf{1}}\end{array}$ & \begin{tabular}{c} 
Realisasi \\
\multicolumn{1}{c}{$\mathbf{X}_{\mathbf{2}}$}
\end{tabular} & \multicolumn{1}{c}{$\mathbf{X}_{\mathbf{1}}-\overline{X_{1}}$} & \multicolumn{1}{c}{$\mathbf{X}_{\mathbf{2}}-\overline{X_{2}}$} & \multicolumn{1}{c}{$\left(\mathbf{X}_{\mathbf{1}}-\overline{X_{1}}\right)^{\mathbf{2}}$} & $\left.\mathbf{X}_{\mathbf{2}}-\overline{X_{2}}\right)^{\mathbf{2}}$ \\
\hline $\mathbf{1}$ & 5.070 & 6.337 & $-62.676,93$ & $-64.570,00$ & $3.928 .396 .927,46$ & $4.169 .284 .900,00$ \\
$\mathbf{2}$ & 19.980 & 24.975 & $-47.766,53$ & $-45.932,00$ & $2.281 .640 .910,58$ & $2.109 .748 .624,00$ \\
$\mathbf{3}$ & 76.103 & 95.129 & $8.356,68$ & $24.222,00$ & $69.834 .017,06$ & $586.705 .284,00$ \\
$\mathbf{4}$ & 85.694 & 107.118 & $17.947,88$ & $36.211,00$ & $322.126 .217,02$ & $1.311 .236 .521,00$ \\
$\mathbf{5}$ & 24.125 & 10.565 & $-43.621,53$ & $-60.342,00$ & $1.902 .837 .443,33$ & $3.641 .156 .964,00$ \\
$\mathbf{6}$ & 20.000 & 3.717 & $-47.746,53$ & $-67.190,00$ & $2.279 .730 .649,58$ & $4.514 .496 .100,00$ \\
$\mathbf{7}$ & 80.000 & 109.291 & $12.253,48$ & $38.384,00$ & $150.147 .649,58$ & $1.473 .331 .456,00$ \\
$\mathbf{8}$ & 231.000 & 210.124 & $163.253,48$ & $139.217,00$ & $26.651 .697 .099,58$ & $19.381 .373 .089,00$ \\
\hline Total & $\mathbf{5 4 1 . 9 7 2 , 2 0}$ & $\mathbf{5 6 7 . 2 5 6 , 0 0}$ & $\mathbf{0 , 0 0}$ & $\mathbf{0 , 0 0}$ & $\mathbf{3 7 . 5 8 6 . 4 1 0 . 9 1 4 , 1 6}$ & $\mathbf{3 7 . 1 8 7 . 3 3 2 . 9 3 8 , 0 0}$ \\
\hline
\end{tabular}

Langkah-langkah pengujian statistik adalah:

1. Merumuskan Ho dan $\mathrm{Ha}$

Ho $: \mu_{1}=\mu_{2}$ (tidak terdapat perbedaan rata-rata yang signifikan antara rencana dengan realisasi produksi)

$\mathrm{Ha}: \mu_{1} \neq \mu_{2}$ (terdapat perbedaan rata-rata yang signifikan antara rencana dengan realisasi produksi) 
2. Menentukan taraf nyata (level of significance)

$$
\begin{aligned}
& \alpha=5 \% \text { untuk } \mathrm{n} \leq 30 \\
& \begin{aligned}
\mathrm{t}_{\text {tabel }} & =\mathrm{t}\left(\alpha / 2 ; \mathrm{n}_{1}+\mathrm{n}_{2}-2\right) \\
& =\mathrm{t}(0,025,8+8-2) \\
& =\mathrm{t}(0,025 ; 14) \\
& =1,761
\end{aligned}
\end{aligned}
$$

3. Statistk Penguji (t)

$$
t=\frac{\overline{\mathrm{X}} 1-\overline{\mathrm{X}} 2}{\sqrt{\frac{(n 1-1) S 1^{2}+(n 2-1) S 2^{2}}{n 1+n 2-2}\left(\frac{1}{n 1}+\frac{1}{n 2}\right)}}
$$

\begin{tabular}{|c|c|c|c|c|c|}
\hline & & Mean & $\mathrm{N}$ & Std. Deviation & $\begin{array}{c}\text { Std. Error } \\
\text { Mean }\end{array}$ \\
\hline \multirow{2}{*}{$\begin{array}{l}\text { Pair } \\
1\end{array}$} & Rencana & 67746,53 & 8 & 73276,78537 & 25907,26 \\
\hline & Realisasi & 70907,00 & 8 & 72886,73497 & 25769,35 \\
\hline
\end{tabular}

4. Kriteria pengujian

Ho diterima apabila: $\mathrm{t}_{\text {hitung }} \leq 1,761$.

Ho ditolak apabila: $\mathrm{t}_{\text {hitung }}>1,761$.

5. Menghitung nilai statistik ( $\mathrm{t})$.

\begin{tabular}{|c|c|c|c|c|c|c|c|c|}
\hline & \multicolumn{5}{|c|}{ Paired Differences } & \multirow[b]{3}{*}{$\mathrm{t}$} & \multirow[b]{3}{*}{ df } & \multirow[b]{3}{*}{ Sig. (2-tailed) } \\
\hline & \multirow[b]{2}{*}{ Mean } & \multirow[b]{2}{*}{ Std. Deviation } & \multirow{2}{*}{$\begin{array}{l}\text { Std. Error } \\
\text { Mean }\end{array}$} & \multicolumn{2}{|c|}{$\begin{array}{l}\text { 95\% Confidence } \\
\text { Interval of the } \\
\text { Difference } \\
\end{array}$} & & & \\
\hline & & & & Lower & Upper & & & \\
\hline $\begin{array}{ll}\text { Pair } 1 & \text { Rencana - Realisasi }\end{array}$ & $-3160,48$ & 18937,41180 & 6695,386 & $-18992,5$ & 12671,60 &,- 472 & 7 & ,651 \\
\hline
\end{tabular}

Tabel 8 Paired Samples Statistics

Tabel 9 Paired Samples Correlations

\begin{tabular}{|ll|r|r|r|}
\hline & & N & Correlation & \multicolumn{1}{c|}{ Sig. } \\
\hline Pair 1 & Rencana \& Realisasi & 8 &, 966 &, 000 \\
\hline
\end{tabular}

Tabel 10 Paired Samples Test 
6. Karena $t_{\text {hitung }}>-1,761$ maka Ho diterima.

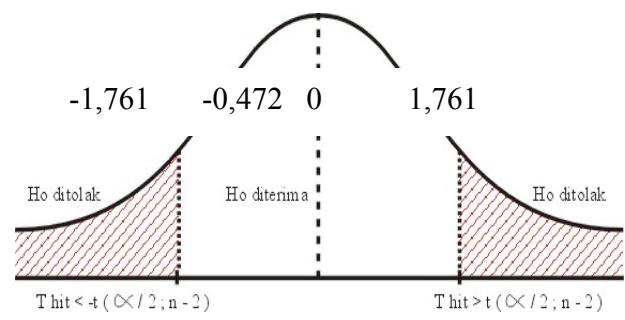

\section{Kesimpulan}

Oleh karena $-t_{\text {tabel }}>-t_{\text {hitung }}(-0,472>-1,761)$ maka Ho diterima, artinya tidak terdapat perbedaan rata-rata yang signifikan antara rencana dengan realisasi produksi sehingga dapat dikatakan antara rencana dengan realisasi produksi adalah efisien karena sebagian besar realisasi produksi lebih besar dari rencana produksi.

\section{Pembahasan Hasil Analisis dan Intrepretasi}

Berdasarkan uji signifikansi korelasi antar variabel menunjukkan hasil koefisien korelasi antara audit internal dengan fungsi produksi untuk menilai efektivitas dan efisiensi proses produksi diperoleh nilai koefisien korelasi sebesar 0,950 yang berarti terdapat hubungan yang sangat kuat. Dengan pengujian hipotesis korelasi diperoleh hasil ada hubungan yang signifikan audit internal dengan fungsi produksi untuk menilai efektivitas dan efisiensi proses produksi, karena Hol ditolak dan Ha1 diterima dimana $t_{\text {hitung }}>t_{\text {tabel }}(16,156>2,048)$.

Berdasarkan uji signifikansi parameter regresi menunjukkan hasil analisis regresi linear sederhana sebesar $\hat{Y}=4,523+0,581 X+\varepsilon$. Hal ini didukung dengan pengujian hipotesis regresi diperoleh $\mathrm{t}_{\text {hitung }}>\mathrm{t}_{\text {tabel }}(16,156>2,048)$ maka ada pengaruh yang signifikan audit internal terhadap fungsi produksi untuk menilai efektivitas dan efisiensi proses produksi karena $\mathrm{Ho} 2$ ditolak dan $\mathrm{Ha} 2$ diterima. Berdasarkan koefisien determinasi dari nilai R square diperoleh hasil 0,903 atau 90,3\%. Hal ini menunjukkan besarnya kontribusi dari audit internal dalam menjelaskan efektivitas dan efisiensi proses produksi sebesar $90,3 \%$ sedangkan sisanya $9,7 \%$ dijelaskan oleh faktor lain yang tidak diteliti atau tidak dimasukkan dalam model.

Berdasarkan uji beda dua rata-rata menunjukkan tidak terdapat perbedaan rata-rata yang signifikan antara rencana dengan realisasi produksi Ho diterima, Ha ditolak atau $t_{\text {hitung }}>-t_{\text {tabel }} \quad(-0,472$ $>-1,761)$. Hasil analisis dan pembahasan menunjukkan adanya hubungan dan pengaruh audit internal terhadap fungsi produksi untuk menilai efektivitas dan efisiensi proses produksi karena H1 / H2 ditolak dan Ha diterima, berarti audit internal atas aktivitas produksi yang dilakukan oleh internal auditor telah sesuai dengan tahap-tahap audit produksi, hal ini dilihat dari segi pemeriksaan operasional dimana adanya sistem terkoordinasi, dan terpadu serta terfokus pada program dan pusatpusat pertanggungjawaban, informasi yang digunakan adalah data yang direncanakan seperti kegiatan produksi, standar dan jasa yang sebenarnya terjadi baik di dalam maupun di luar organisasi, prosesnya cenderung teratur, yaitu periodesasi waktu, misalnya harian, mingguan, bulanan, tahunan. Adanya struktur organisasi yang secara tegas dan jelas memisahkan wewenang, tanggungjawab dan tugas masing-masing manajemen. Audit internal atas proses produksi dibuat agar individu dalam organisasi turut berperan serta dalam mencapai sasaran perusahaan secara optimal. Audit internal atas fungsi produksi merupakan hasil evaluasi dan penilaian kinerja yang dapat digunakan sebagai acuan dalam penyusunan rencana kerja, baik masing-masing pusat pertanggungjawaban maupun perusahaan secara keseluruhan untuk periode yang akan datang. 


\section{SIMPULAN}

Berdasarkan pengolahan data dengan menggunakan statistik antara audit internal terhadap fungsi produksi untuk menilai efektivitas dan efisiensi proses produksi di PT Sumber Nitrat Jaya dapat disimpulkan sebagai berikut.

Uji signifikansi korelasi antarvariabel menunjukkan hasil koefisien korelasi antara audit internal dengan fungsi produksi untuk menilai efektivitas dan efisiensi proses produksi diperoleh nilai koefisien korelasi sebesar 0,950 yang berarti terdapat hubungan yang sangat kuat. Demikian pula pengujian hipotesis korelasi diperoleh hasil terdapatnya hubungan yang signifikan audit internal dengan fungsi produksi untuk menilai efektivitas dan efisiensi proses roduksi di PT Sumber Nitrat Jaya, karena Ho1 ditolak dan Ha1 diterima dimana $t_{\text {hitung }}>t_{\text {tabel }}(16,156>2,048)$.

Uji signifikansi parameter regresi menunjukkan hasil analisis regresi linear sederhana sebesar $\hat{\mathrm{Y}}=4,523+0,581 \mathrm{X}+\varepsilon$. Hal ini didukung dengan pengujian hipotesis regresi diperoleh $\mathrm{t}_{\text {hitung }}>\mathrm{t}_{\text {tabel }}$ $(16,156>2,048)$, maka ada pengaruh yang signifikan audit internal terhadap fungsi produksi untuk menilai efektivitas dan efisiensi proses produksi di PT Sumber Nitrat Jaya karena Ho2 ditolak dan Ha2 diterima. Hal ini juga didukung dengan nilai $\mathrm{R}$ square diperoleh hasil 0,903 atau 90,3\%. Hal ini menunjukkan besarnya kontribusi dari audit internal dalam menjelaskan efektivitas dan efisiensi proses produksi sebesar 90,3\% sedangkan sisanya 9,7\% dijelaskan oleh faktor lain yang tidak diteliti atau tidak dimasukkan dalam model.

Saran-saran yang dapat diajukan oleh peneliti bagi penelitian lebih lanjut adalah sebagai berikut. Peneliti berikutnya yang berminat untuk mengembangkan topik yang sama sebaiknya menambahkan jumlah variabel yang berbeda, dan menambah jumlah sampel perusahaan yang diteliti. Karena semakin banyak perusahaan yang diteliti, hasil penelitian akan semakin dapat digeneralisasi. Selain itu, peneliti berikutnya sebaiknya mengambil periode pengamatan yang lebih panjang, sehingga penelitian yang dilakukan memberikan hasil yang lebih akurat dan dapat mewakili seluruh populasi yang ada.

\section{DAFTAR PUSTAKA}

Agoes, S. (2004). Auditing (Pemeriksaan Akuntan) oleh Kantor Akuntan Publik. Edisi 3. Jakarta: Lembaga Penerbit FE Universitas Indonesia.

Arens, A. A., dan Loebbecke, J. K. (2003). Auditing Suatu Pendekatan Terpadu. Edisi Indonesia. Terjemahan Amir Abadi Jusuf. Jakarta: Erlangga.

Indriantoro, N., dan Supomo, B. (2002). Metode Penelitian Bisnis. Yogyakarta: BPFE Yogyakarta.

Jusup, A. H. (2001). Auditing (Pengauditan). Buku Satu. Yogyakarta: STIE YKPN. . (2001). Auditing (Pengauditan). Buku Dua. Yogyakarta: STIE YKPN.

Messier, W. F., et.al. (2004). Auditing and Assurance Services A Systematic Approach. Edisi 4. McGrawHill Irwin.

Mulyadi. (2000). Akuntansi Biaya. Edisi Kelima. Yogyakarta: Aditya Media.

Mulyadi dan Puradiredja, K. (2002). Auditing. Buku Satu. Jakarta: Salemba Empat. 

(2002). Auditing. Buku Dua. Jakarta : Salemba Empat.

Prastito, A. (2005). Cara Mudah Mengolah Data Statistik. Jakarta: Gramedia Pustaka Utama.

Santosa, P. B., dan Ashari. (2005). Analisis Statistik dengan Microsoft Excell dan SPSS. Yogyakarta: Andi.

Sekaran, U. (2002). Research Methods for Business. USA: Southern Ilinois University.

Siagian, D. (2000). Metode Statistika untuk Bisnis dan Ekonomi. Jakarta: Gramedia Pustaka Utama.

Sugiyono. (2002). Metode Penelitian Bisnis. Bandung: CV Alfabeta. (2006). Metode Penelitian. Jakarta: Gramedia Pustaka Utama.

Swastha, B., dan Sukotjo, I. (2002). Pengantar Bisnis Modern. Edisi 3. Yogyakarta: Liberty.

Triton, P.B. (2006). SPSS 13.0 Tarapan: Riset Statistik Parametrik. Yogyakarta: ANDI. 